Article

\title{
Livelihood Assets and Strategies among Rural Households: Comparative Analysis of Rice and Dryland Terrace Systems in China
}

\author{
Lun Yang ${ }^{1,2}$, Moucheng Liu ${ }^{1, *}$, Fei Lun ${ }^{3,4}$, Qingwen Min ${ }^{1,2}$, Canqiang Zhang ${ }^{5}$ and Heyao Li ${ }^{1,2}$ \\ 1 Institute of Geographic Sciences and Natural Resources Research, Chinese Academy of Sciences, \\ 11A Datun Road, Beijing 100101, China; rebussy@163.com (L.Y.); minqw@igsnrr.ac.cn (Q.M.); \\ tonymarigold@live.com (H.L.) \\ 2 University of Chinese Academy of Sciences, No. 19A Yuquan Road, Beijing 100049, China \\ 3 College of Land Science and Technology, China Agricultural University, Beijing 100193, China; \\ lunfei@cau.edu.cn \\ 4 Key Laboratory of Agricultural Land Quality, Ministry of Land and Resources, Beijing 100193, China \\ 5 Research Center for Rural Economy, Ministry of Agriculture and Rural Affairs, Beijing 100810, China; \\ zhangcq2010@163.com \\ * Correspondence: liumc@igsnrr.ac.cn; Tel./Fax: +86-10-6488-8202
}

Received: 13 June 2018; Accepted: 17 July 2018; Published: 19 July 2018

\begin{abstract}
The livelihood of peasant households is one of the selection criteria of Globally Important Agricultural Heritage Systems and a critical factor that affects agricultural heritage system conservation and inheritance. Taking the Honghe Hani Rice Terraces System (HHRTS) and Shexian Dryland Terraces System (SDTS) as examples, we investigated 304 households through a participatory rural appraisal method to discuss the livelihood assets and strategies of households in agricultural heritage systems. From the viewpoint of livelihood strategies, household strategies can be divided into pure agricultural, nonagricultural, and part-time agricultural strategies. The livelihood strategies of households in the HHRTS feature a higher proportion of nonagricultural, while those in the SDTS have a diverse distribution. With respect to livelihood assets, we constructed a livelihood assets accounting framework to highlight the important role of traditional culture and information technology in agricultural activities. The average livelihood assets value in the HHRTS and SDTS was 2.249 and 1.832, respectively. Then, applying the multinomial logit model, we quantitatively analyzed the relationship between livelihood assets and strategies. The results show that in both terrace systems, the understanding of traditional agricultural knowledge is important to suppress the shift of pure agricultural households to nonagricultural or part-time agricultural households. Therefore, in order to achieve dynamic conservation of terrace systems, it is necessary to effectively increase the cultural assets level of households, especially farmers' understanding of traditional agricultural knowledge.
\end{abstract}

Keywords: agricultural heritage systems; terrace systems; sustainable development; livelihood strategies; livelihood assets

\section{Introduction}

In 2002, the Food and Agriculture Organization (FAO) of the United Nations (UN) proposed the concept of Globally Important Agricultural Heritage Systems (GIAHS) with an emphasis on the need to ensure the dynamic conservation of these systems. The FAO's aim was to build a system of globally important agricultural heritages and related landscapes to conserve their biodiversity, knowledge, and culture as well as make them globally recognized and protected as a foundation for 
sustainable management [1-3]. As of the end of 2017, 50 traditional agricultural systems located in 20 countries worldwide had been placed on the GIAHS list, four of which are terrace systems in China, South Korea, and the Philippines [4]. Starting in 2012, China launched a similar national program, called the National Important Agricultural Heritage Systems of China (China-NIAHS). By the end of 2017, a total of 91 traditional agricultural systems had been ranked as China-NIAHS, including seven terrace systems [5]. As a key focus and important aspect of agricultural heritage systems (AHS), terraces are considered a typical upland agricultural ecosystem and constitute one of the most evident anthropogenic imprints on the landscape, covering a considerable part of the terrestrial landscape [6-8].

As human-created landscapes, terraces are ubiquitous on hill slopes and in other mountainous regions $[9,10]$. They continue to perform their production function while serving as pronounced evidence of human history and its diverse cultures and civilizations [11,12] and offering evidence of previous societies' abundant production technology, agricultural management experience, and traditional agricultural knowledge $[10,13]$. In China, rice terraces and dryland terraces are two common types of terrace systems. Rice terraces are mainly located in the south of China, such as in Yunnan, Guizhou, Hunan, and Guangxi provinces, with the Honghe Hani Rice Terraces System (HHRTS) as an example. The HHRTS has a history stretching back over 1300 years, and it has extremely high historical, cultural, ecological, economic, and aesthetic value [14-16]. The vertical distribution of the forest-village-terrace-river ecological landscape represents the typical characteristics of the HHRTS $[14,16]$. In 2010, the HHRTS was rated as a GIAHS site by the FAO and included as a World Cultural Heritage site by the United Nations Educational, Scientific, and Cultural Organization (UNESCO). It was also ranked among China-NIAHS in 2013 [5,17,18]. In contrast, dryland terraces are mostly found in northern China, such as in Hebei, Shanxi, and Shaanxi provinces, with the Shexian Dryland Terraces System (SDTS) as a typical example. With a history of over 700 years, the SDTS was ranked among China-NIAHS in 2014 [5]. Different from the HRRTS, whose field ridges are composed of soil, in the SDTS stones are piled to build "stone weirs" as field ridges [19]. Generally, both rice and dryland terraces reflect human wisdom in adapting to and making use of available natural resources.

Terrace systems have sustained a small-scale farming model for a long time. Because peasant households are the most basic socioeconomic and decision-making units in rural areas in China, their means of livelihood and survival strategies determine their ways of exploiting natural resources and utilization efficiency and thus have a profound influence on the ecological environment [20-23]. Thus, the five selection criteria of GIAHS sites include food and livelihood security [1]. The rapid development of tourism, industrialization, and urbanization has great impacts on terrace agriculture because of its low level of mechanization, highly labor-intensive nature, and the low comparative benefits of agricultural production [24-26]. At the level of peasant households, such impact is manifested as households changing from a pure agricultural livelihood strategy to a diversified livelihood strategy that integrates tourist reception and a nonagricultural livelihood strategy that features seeking work as migrant workers [27-29]. In addition, at the agricultural system level, some places have discontinued farming and collapsed terraces [16,30]. As a result, some old-line traditional tillage methods and agricultural landscapes have gradually disappeared, which poses a threat to the underlying structure that has long maintained the stability of terrace systems [2]. Therefore, it is necessary to conduct an in-depth study of the livelihood strategy transformation model pursued by households in the terrace systems and determine the factors influencing the choice of strategy.

This paper starts by examining the livelihood assets of households, with a focus on livelihood strategies. Then, the HHRTS and SDTS are selected for comparative study, and the relationship between livelihood assets and strategies is discussed. The factors that influence the household selection of livelihood strategy are then used to provide suggestions for the sustainable development of terrace systems and a mountainous ecological agricultural model. 


\section{Materials and Methods}

\subsection{Study Area}

The HHRTS is mainly distributed in the basin of the middle and lower reaches of the Red River in the Ailao Mountains in southwest China and involves 4 counties: Yuanyang, Honghe, Jinping, and Lüchun. The terraced landscape in Yuanyang is the most famous. Yuanyang County is situated in southern Yunnan $\left(102^{\circ} 27^{\prime}-103^{\circ} 13^{\prime} \mathrm{E}, 22^{\circ} 49^{\prime}-23^{\circ} 19^{\prime} \mathrm{N}\right)$, and its main landform is mountainous, with an elevation of 114.00-2939.60 m, annual average rainfall of $899.50 \mathrm{~mm}$, and 35,496.67 ha of rice terraces [31]. We chose Qingkou village and Duoyishu village in Yuanyang County, located in the core areas of the HHRTS, as the research areas of the rice terrace system.

Situated in southwestern Hebei and with a geographical range between $36^{\circ} 17^{\prime}-36^{\circ} 55^{\prime} \mathrm{N}$, $113^{\circ} 26^{\prime}-113^{\circ} 67^{\prime} \mathrm{E}$, She County is a typical Taihang Mountains county, with an elevation of 203.00-1562.90 $\mathrm{m}$ and annual rainfall of $540.50 \mathrm{~mm}$. The SDTS covers an area of 17,866.67 ha, 233.33 ha of which are dryland terraces in its core area [19]. We selected the main distribution areas of SDTS-Wangjinzhuang village as the research area of the dryland terrace system. Wangjinzhuang village consists of 5 administrative villages, with a resident population of 4520 people.

\subsection{Data Sources}

In August 2017 and April 2018, investigations into households in the HHRTS and SDTS, respectively, were conducted. These investigations included several steps. First, village heads and household representatives were consulted to learn basic information. On this basis, a questionnaire and participatory rural appraisal (PRA) were combined to collect data on sampled households [32]. In the HHRTS and SDTS, the number of households chosen randomly for investigation was 150 and 154, respectively (Table 1). The investigation mainly aimed to determine (1) livelihood assets of households, which encompasses natural assets, physical assets, financial assets, human assets, and social assets [33,34], as well as the cultural assets highlighted in this paper; and (2) annual household income and expenditure, which involve actual income and amount of expenses, sources of income, and purposes of expenditure.

Table 1. Numbers of households surveyed in different villages. HHRTS, Honghe Hani Rice Terraces System; SDTS, Shexian Dryland Terraces System.

\begin{tabular}{ccccc}
\hline \multirow{2}{*}{ HHRTS } & Village & Total Households & Surveyed Households & Proportion \\
& Qingkou & 92 & 65 & $70.65 \%$ \\
& Duoyishu & 103 & 85 & $82.52 \%$ \\
\hline \multirow{2}{*}{ SDTS } & Wangjinzhuang Yijie & 185 & 64 & $34.60 \%$ \\
& Wangjinzhuang Erjie & 218 & 90 & $41.28 \%$ \\
\hline \multirow{2}{*}{ Total } & & 598 & 304 & $50.84 \%$ \\
\hline
\end{tabular}

\subsection{Classification of Livelihood Strategies}

Generally, household livelihood strategies can be divided into 3 types: agriculture intensification, livelihood diversification, and migration $[33,34]$. Scholars utilize different criteria to classify livelihood strategies, for example, by the diversity of the agricultural livelihood strategy $[21,35,36]$ or by income structure, source of income, and development direction [37-40]. Widely used quantitative analysis methods include k-means cluster analysis and latent class cluster analysis [41]. In China, the practice of classifying peasants by their income structure is widely used [42-44]. In 2002, the Chinese Academy of Social Sciences proposed a method to classify the income structures of peasants such that households where agricultural income accounts for over 95\% of family income are defined as pure agricultural households, those where nonagricultural income accounts for over $95 \%$ are defined as nonagricultural households, and those where nonagricultural income accounts for 5-95\% are recognized as part-time 
agricultural households. On this basis, the National Bureau of Statistics of China proposed a new classification method in 2005, decreasing the income threshold from $95 \%$ to $90 \%[43,45]$.

Compared with other rural areas, households in AHS have mostly adopted a diversified livelihood strategy, and the proportion of agricultural income to total income is generally lower, less than 3/4, on average [2,46]. Three sources of agricultural income were identified: cultivation of grain or commercial crops, forestry and fruit growing, and poultry farming. Sources of nonagricultural income can be divided into offering local tourist reception, working in cities, and receiving a subsidy from the government. Therefore, on the basis of a summary of the previous findings combined with the practical situation of the HHRTS and SDTS, this paper defines households whose agricultural income accounts for over $75 \%$ of family income as pure agricultural households (LS1), those whose nonagricultural income accounts for over $75 \%$ as nonagricultural households (LS2), and those whose nonagricultural income accounts for $25 \%$ to $75 \%$ as part-time agricultural households (LS3).

\subsection{Livelihood Assets Accounting}

Livelihood assets are not merely "things" that are input into a production process, but also serve as a basis of power to act and ultimately bring about changes in society [33,34]. Numerous scholars have performed comprehensive calculations, comparative studies, and vulnerability analyses of livelihood assets at different spaces and time scales [47-50]. However, most of that research was based on an indicator system drawing on the Sustainable Livelihoods Approach proposed by the UK Department for International Development (DFID) [33,34,51], and the literature has abundant empirical studies but a relative lack of theoretical explorations.

\subsubsection{Indicators of Livelihood Assets}

This paper is based on the Sustainable Livelihoods Approach developed by DFID [33,34]. It highlights the important role of traditional culture and information technology in agricultural livelihood activities, building a livelihood assets assessment framework suitable for AHS. The framework divides livelihood assets into 6 types: natural assets, physical assets, financial assets, human assets, social assets, and cultural assets [48,50,52], identifying 18 indicators in total (Table 2). Cultural assets are used to reflect traditional agricultural knowledge, agricultural technology, and internet information used by households when making a living.

Households in AHS have formed and accumulated rich traditional knowledge in the long process of production and life [14]. For example, households in the HHRTS have unique national cultural customs, including festival activities like Shi Yue Nian and Long Street Banquet and taboos like Magic Woods and Mountain Worship, which contain the wisdom of sustainable utilization of natural resources $[27,46,53]$. In the SDTS, by constructing stone-weir terraces, peasants have realized efficient utilization of soil and stone. Meanwhile, the locally formed coupled structure "donkey-pepper-stone weir" is of great significance to local environmental conservation and social harmony as an important component of community culture in villages [54]. In addition, the comprehensive popularization of smartphones has accustomed peasants to receiving the latest information and technology via mobile internet. The research areas have gotten full internet access coverage, and residents 20 years of age and older who have a smartphone with internet access account for $88.92 \%$ of the total population. 
Table 2. Indicators and descriptions of livelihood assets.

\begin{tabular}{|c|c|c|c|c|}
\hline Type & No. & Indicator Name & Weight & Indicator Definition \\
\hline \multirow{3}{*}{$\begin{array}{l}\text { Natural } \\
\text { assets }\end{array}$} & N1 & Cultivated land area & 0.416 & \multirow{3}{*}{$\begin{array}{l}\text { Actual number } \\
1=\text { Worst, } 2=\text { Bad, } 3=\text { Average, } 4= \\
\text { Well, } 5=\text { Best } \\
1=\text { Very far, } 2=\text { Relatively far, } 3= \\
\text { Common, } 4=\text { Relatively close, } 5= \\
\text { Very close }\end{array}$} \\
\hline & N2 & Quality of cultivated land & 0.279 & \\
\hline & N3 & Distance between residence and cultivated land & 0.305 & \\
\hline \multirow{3}{*}{$\begin{array}{l}\text { Physical } \\
\text { assets }\end{array}$} & P1 & Quantity of consumer goods & 0.346 & \multirow{3}{*}{$\begin{array}{l}\text { Actual number, such as TV sets and } \\
\text { washing machines, etc. } \\
\text { Actual number, such as wooden tools } \\
\text { and motorbikes, etc. } \\
\text { Actual number, such as smartphones } \\
\text { and computers, etc. }\end{array}$} \\
\hline & $\mathrm{P} 2$ & Quantity of agricultural tools & 0.220 & \\
\hline & P3 & Quantity of internet devices & 0.434 & \\
\hline \multirow{3}{*}{$\begin{array}{l}\text { Financial } \\
\text { assets }\end{array}$} & F1 & Amount of household savings & 0.145 & \multirow{3}{*}{$\begin{array}{l}\text { Actual number } \\
\text { Actual number, including personal } \\
\text { loans and bank loans } \\
\text { Actual number }\end{array}$} \\
\hline & F2 & Amount of household debts & 0.444 & \\
\hline & F3 & Number of livestock & 0.411 & \\
\hline \multirow{3}{*}{$\begin{array}{l}\text { Human } \\
\text { assets }\end{array}$} & H1 & Number of laborers & 0.131 & \multirow{3}{*}{$\begin{array}{l}\text { Actual number } \\
1=\text { Worst, } 2=\text { Bad, } 3=\text { Average, } 4= \\
\text { Well, } 5=\text { Best; including the health of } \\
\text { the whole household and the } \\
\text { education of its members } \\
\text { Actual number }\end{array}$} \\
\hline & $\mathrm{H} 2$ & Agricultural technical capacity of laborers & 0.438 & \\
\hline & $\mathrm{H} 3$ & Labor productivity of agricultural production & 0.431 & \\
\hline \multirow{3}{*}{$\begin{array}{l}\text { Social } \\
\text { assets }\end{array}$} & S1 & Degree of neighborhood communication & 0.212 & \multirow{3}{*}{$\begin{array}{l}1=\text { Worst, } 2=\text { Bad, } 3=\text { Average, } 4= \\
\text { Well, } 5=\text { Best } \\
\text { Actual number } \\
1=\text { Worst, } 2=\text { Bad, } 3=\text { Average, } 4= \\
\text { Well, } 5=\text { Best }\end{array}$} \\
\hline & S2 & Number of relatives in the same village & 0.355 & \\
\hline & S3 & Degree of satisfaction in the village & 0.433 & \\
\hline \multirow{3}{*}{$\begin{array}{l}\text { Cultural } \\
\text { assets }\end{array}$} & $\mathrm{C} 1$ & Understanding of village regulations and rules & 0.095 & \multirow{3}{*}{$\begin{array}{l}1=\text { Worst, } 2=\text { Bad, } 3=\text { Average, } 4= \\
\text { Well, } 5=\text { Best } \\
1=\text { Worst, } 2=\text { Bad, } 3=\text { Average, } 4= \\
\text { Well, } 5=\text { Best } \\
1=\text { Worst }, 2=\text { Bad, } 3=\text { Average, } 4= \\
\text { Well, } 5=\text { Best }\end{array}$} \\
\hline & $\mathrm{C} 2$ & $\begin{array}{l}\text { Understanding of traditional agricultural } \\
\text { knowledge }\end{array}$ & 0.255 & \\
\hline & $\mathrm{C} 3$ & Frequency of internet use & 0.650 & \\
\hline
\end{tabular}

Before the empirical analysis, Stata MP14 statistical software [55] was used to examine the linear correlation and multicollinearity of the above-mentioned 18 indicators. The results show that there was no linear correlation or multicollinearity between them.

\subsubsection{Data Normalization}

We used the maximizing deviation method to normalize data $[50,56-58]$ as follows:

$$
x_{i j}^{\prime}=\left(x_{i j}-x_{\min }\right) /\left(x_{\max }-x_{\min }\right)
$$

where $x_{i j}^{\prime}$ is the normalized value of livelihood assets indicator $\mathrm{j}$ of sample $\mathrm{i}, x_{i j}$ is the actual value of indicator $\mathrm{j}$ of sample $\mathrm{i}$, and $x_{\max }$ and $x_{\min }$ are the maximum and minimum of livelihood assets of indicator $\mathrm{j}$, respectively.

\subsubsection{Measurement of Weights}

Generally speaking, the entropy evaluation method $[59,60]$ was used to determine the weight of data on multiple samples to overcome information overlapping and subjectivity caused by artificial weighting. The process of using the entropy evaluation method is as follows:

$$
p_{i j}=x_{i j}^{\prime} / \sum_{i=1}^{m} x_{i j}^{\prime}
$$




$$
\begin{aligned}
& e_{l j}=-1 / \ln m \sum_{i=1}^{m} p_{i j} \ln p_{i j} \\
& w_{j}=\left(1-e_{j}\right) / \sum_{j=1}^{n}\left(1-e_{j}\right)
\end{aligned}
$$

where $x_{i j}^{\prime}$ is the normalized value of livelihood assets indicator $\mathrm{j}$ of sample $\mathrm{i}, p_{i j}$ is the weight of livelihood assets indicator $\mathrm{j}$ in sample $\mathrm{i}, e_{j}$ represents the entropy value of livelihood assets indicator $\mathrm{j}$, and $w_{j}$ is the weight of livelihood assets indicator $\mathrm{j}$. Also:

$$
\mathrm{LA}=\sum_{j=1}^{n} w_{j} x_{i j}^{\prime}
$$

where LA is the value of a livelihood asset, and household assets value in this paper is an average among sampled households in the research areas.

\subsection{Analysis of Livelihood Assets Effect on Livelihood Strategies}

The livelihood strategies of a peasant are dynamic, which means that when environmental background, livelihood assets, policies, and systems undergo drastic changes, households tend to transform their livelihood strategies to adapt to a new man-land relationship [20]. In general, livelihood assets play a dominant role in the transformation of livelihood strategies. For example, natural assets, represented by land, are the main constraint for the majority of impoverished households [61-64], while in areas with rapid urbanization, human assets propel households to turn from agricultural operation to nonagricultural employment [65-68]. Therefore, with the livelihood assets indicator as an independent variable and the type of livelihood strategy as a dependent variable, we used the multinomial logit model $[50,69]$ for the regression analysis of analyzed and filtered factors that influence households in choosing their livelihood strategies. The model is as follows:

Random effects brought by choosing livelihood strategy j for households are calculated by:

$$
U_{i j}=x_{i j}^{\prime} \beta+\varepsilon_{i j}(i=1, \ldots, n ; j=1,2,3)
$$

Obviously, household i chooses livelihood strategy j only when livelihood strategy j brings more effects than any other strategy, so the probability that agricultural household i will choose livelihood strategy $\mathrm{j}$ can be put as:

$$
\mathrm{P}\left(y_{i}=\mathrm{j} \mid x_{i}\right)=\mathrm{P}\left(U_{i j} \geq U_{i k}, \forall k \neq j\right)
$$

Hence, the probability that household i will choose livelihood strategy $\mathrm{j}$ can be expressed as:

$$
\mathrm{P}\left(y_{i}=j \mid x_{i}\right)=\frac{\exp \left(x_{i}^{\prime} \beta_{j}\right)}{\sum_{k=1}^{j} \exp \left(x_{i}^{\prime} \beta_{k}\right)}(i=1, \ldots, n ; j=1,2,3)
$$

We chose pure agricultural households as a reference to discuss which livelihood assets indicators significantly influence the process of changing from a pure agricultural household to a nonagricultural or part-time agricultural household.

\section{Results}

\subsection{Livelihood Strategies and Household Types}

On the basis of the sources and structure of household income, we divided terrace system households into three types: pure agricultural households (LS1), nonagricultural households (LS2), and part-time agricultural households (LS3). In general, the HHRTS has the largest number of LS2 households, which means their livelihood strategies have a higher degree of nonagriculturization. 
SDTS households, however, were more likely to fall into the LS3 category, indicating a high level of diversity of livelihood strategies in the SDTS (Figure 1).
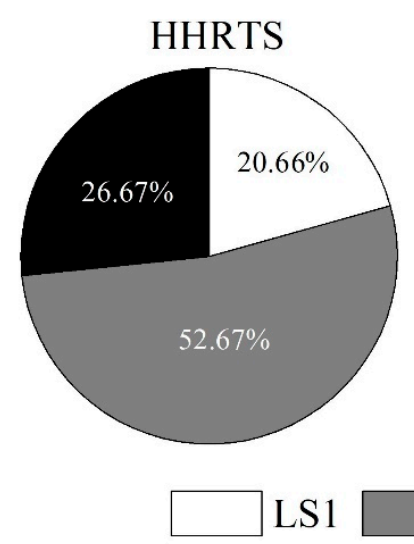

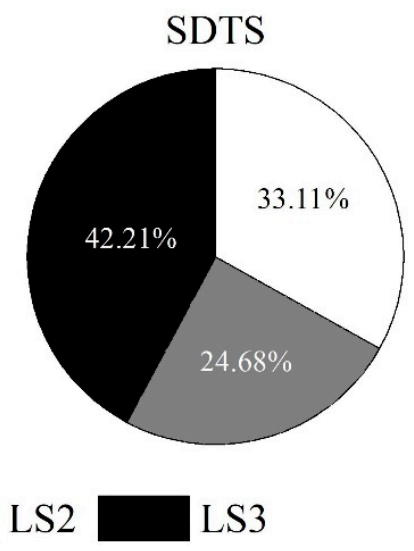

Figure 1. Percentages of different types of households.

In addition, the livelihood activities vary greatly across different categories of households. Owing to their unique natural scenery and cultural landscape, terrace systems in China have become popular tourist destinations in recent years. The survey results show that tourism reception has gradually come to play an important role in the livelihood activities of households (Table 3).

Table 3. Livelihood activities of different types of households.

\begin{tabular}{ccl}
\hline & Household Type & \multicolumn{1}{c}{ Livelihood Activities } \\
\hline \multirow{3}{*}{ LS1 } & $\begin{array}{l}\text { Cultivating food crops like hybrid rice, red rice, maize, and soybean; } \\
\text { cultivating commercial crops like banana, sugarcane, and rubber tree; and } \\
\text { breeding poultry like ducks and chickens. }\end{array}$ \\
\cline { 2 - 3 } & LS2 & $\begin{array}{l}\text { Building homestays to receive tourists, making and selling souvenirs, and } \\
\text { going out as migrant workers in low farming season. }\end{array}$ \\
\cline { 2 - 4 } & LS3 & $\begin{array}{l}\text { In busy farming season, growing food crops and commercial crops. In slack } \\
\text { farming season, going out as migrant workers. In peak tourist season, } \\
\text { engaging in some tourist reception activities, such as acting as helpers in } \\
\text { households with a guesthouse and working as temporary drivers. }\end{array}$ \\
\hline SDTS & $\begin{array}{l}\text { Obtaining income by growing mainly Sichuan peppers and cultivating } \\
\text { Chinese herbal medicines such as Bupleurum chinense, Salvia miltiorrhiza, } \\
\text { and Scutellaria baicalensis on the side. }\end{array}$ \\
\cline { 2 - 3 } & LS2 & Primarily engaging in local tourist reception and working in cities. \\
\hline
\end{tabular}

\subsection{Characteristics of Different Household Types}

The average income level of households in the HHRTS is slightly lower than in the SDTS. Specifically, the average annual income in the HHRTS is 41,372 yuan. As before, average annual agricultural income is 7491 yuan and annual nonagricultural income is 33,882 yuan. In contrast, the average annual household income in the SDTS is 50,040 yuan. The average annual agricultural income is 29,883 yuan, whereas the average annual nonagricultural income is 20,157 yuan. These findings demonstrate that nonagricultural income is the main income in the HHRTS, while agricultural income contributed the largest proportion of annual household income in the SDTS.

For pure agricultural households, incomes in the SDTS are far higher than in corresponding HHRTS households. On the contrary, for nonagricultural households, income levels in the HHRTS are 
much higher than in the SDTS. Besides, part-time agricultural households have similar income levels in both terrace systems (Figure 2).
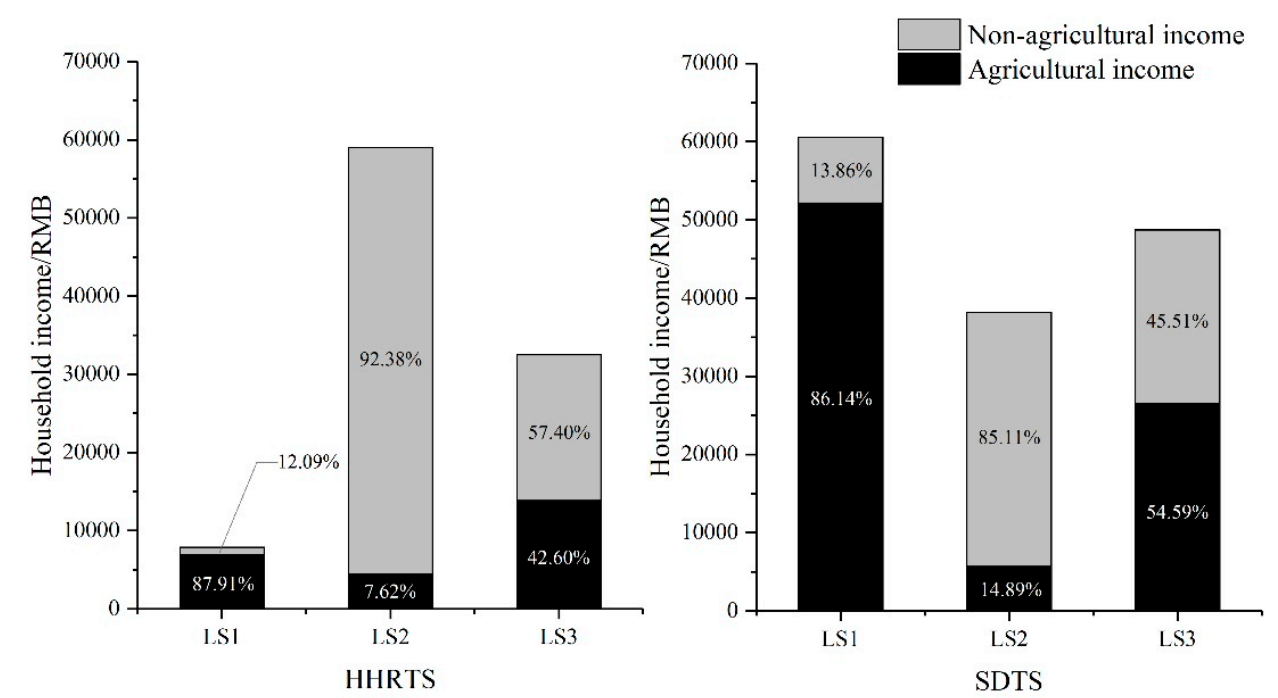

Figure 2. Average income levels of peasant households in the HHRTS and SDTS.

Regarding the average household composition, the most significant differences are householder gender and ethnicity. HHRTS households have higher proportions of non-Han and female householders, which is closely linked to the multiethnic integration in Hani terrace areas and the tradition of women being the major workforce. When comparing characteristics of households choosing the same livelihood strategy across the two examined terrace systems, great variations were found. For example, among pure agricultural households, householders in the HHRTS are older and families have more skilled peasants in working crops. In the SDTS, in contrast, the householders are better educated and families have overall better health (Table 4).

Table 4. Descriptive statistics of the household survey in HHRTS and SDTS.

\begin{tabular}{|c|c|c|c|c|c|c|c|c|c|}
\hline & & \multicolumn{4}{|c|}{ HHRTS } & \multicolumn{4}{|c|}{ SDTS } \\
\hline & & LS1 & LS2 & LS3 & Average & LS1 & LS2 & LS3 & Average \\
\hline \multicolumn{2}{|c|}{ Householder's age (years) } & 43.74 & 41.01 & 38.53 & 40.91 & 40.69 & 42.79 & 42.35 & 41.91 \\
\hline \multicolumn{2}{|c|}{$\begin{array}{l}\text { Education duration of } \\
\text { householder (years) }\end{array}$} & 7.84 & 9.25 & 9.95 & 9.15 & 8.00 & 7.50 & 7.48 & 7.66 \\
\hline \multicolumn{2}{|c|}{$\begin{array}{l}\text { Number of skilled peasants } \\
\text { within a family (n) }\end{array}$} & 1.45 & 1.52 & 1.53 & 1.51 & 0.86 & 4.29 & 0.97 & 0.91 \\
\hline \multirow{2}{*}{$\begin{array}{l}\text { Householder's } \\
\text { gender }(\%)\end{array}$} & Male & 70.97 & 58.23 & 60.00 & 61.32 & 90.20 & 89.47 & 90.77 & 90.26 \\
\hline & Female & 29.03 & 41.77 & 40.00 & 38.68 & 9.80 & 10.53 & 9.23 & 9.74 \\
\hline \multirow{2}{*}{$\begin{array}{l}\text { Householder's } \\
\text { nationality }(\%)\end{array}$} & Han & 48.39 & 46.48 & 42.50 & 48.67 & 100.00 & 100.00 & 100.00 & 100.00 \\
\hline & Non-Han & 51.61 & 53.52 & 57.50 & 51.33 & - & - & - & - \\
\hline \multirow{5}{*}{$\begin{array}{l}\text { Overall health } \\
\text { condition of the } \\
\text { family }(\%)\end{array}$} & Worst & 19.35 & 15.19 & 17.50 & 16.67 & - & 2.63 & - & 0.65 \\
\hline & Bad & 9.68 & 1.27 & 12.50 & 6.00 & 7.84 & 2.63 & 4.62 & 5.20 \\
\hline & Average & 6.45 & 6.33 & 5.00 & 6.00 & 7.84 & 7.90 & 3.08 & 5.84 \\
\hline & Well & 9.68 & 31.64 & 27.50 & 26.00 & 39.22 & 36.84 & 33.85 & 36.36 \\
\hline & Best & 54.84 & 45.57 & 37.50 & 45.33 & 45.10 & 50.00 & 58.45 & 51.95 \\
\hline
\end{tabular}

\subsection{Assets of Different Livelihood Strategies}

According to the setting of livelihood asset indicators and the data normalization approach in this paper, the maximum livelihood asset value was 6 , and the minimum was 0 . The maximum of each livelihood asset was 1 , and the minimum was 0 . 
The results show that the average livelihood asset value of households in the HHRTS and SDTS is 2.249 and 1.832, respectively. Specifically, HHRTS households have more cultural and human assets, which are 0.590 and 0.492 , respectively, but their natural and financial assets are insufficient, with values of 0.232 and 0.138 , respectively. SDTS households have more social and cultural assets, with values of 0.584 and 0.338 , respectively, but insufficient human and financial assets, with values of 0.247 and 0.036 , respectively. A comparison of livelihood assets in the two kinds of terrace systems shows that although physical assets are at a similar level, households in the HHRTS have advantages in cultural, human, and financial assets, whereas households in the SDTS have advantages in natural and social assets (Figure 3).

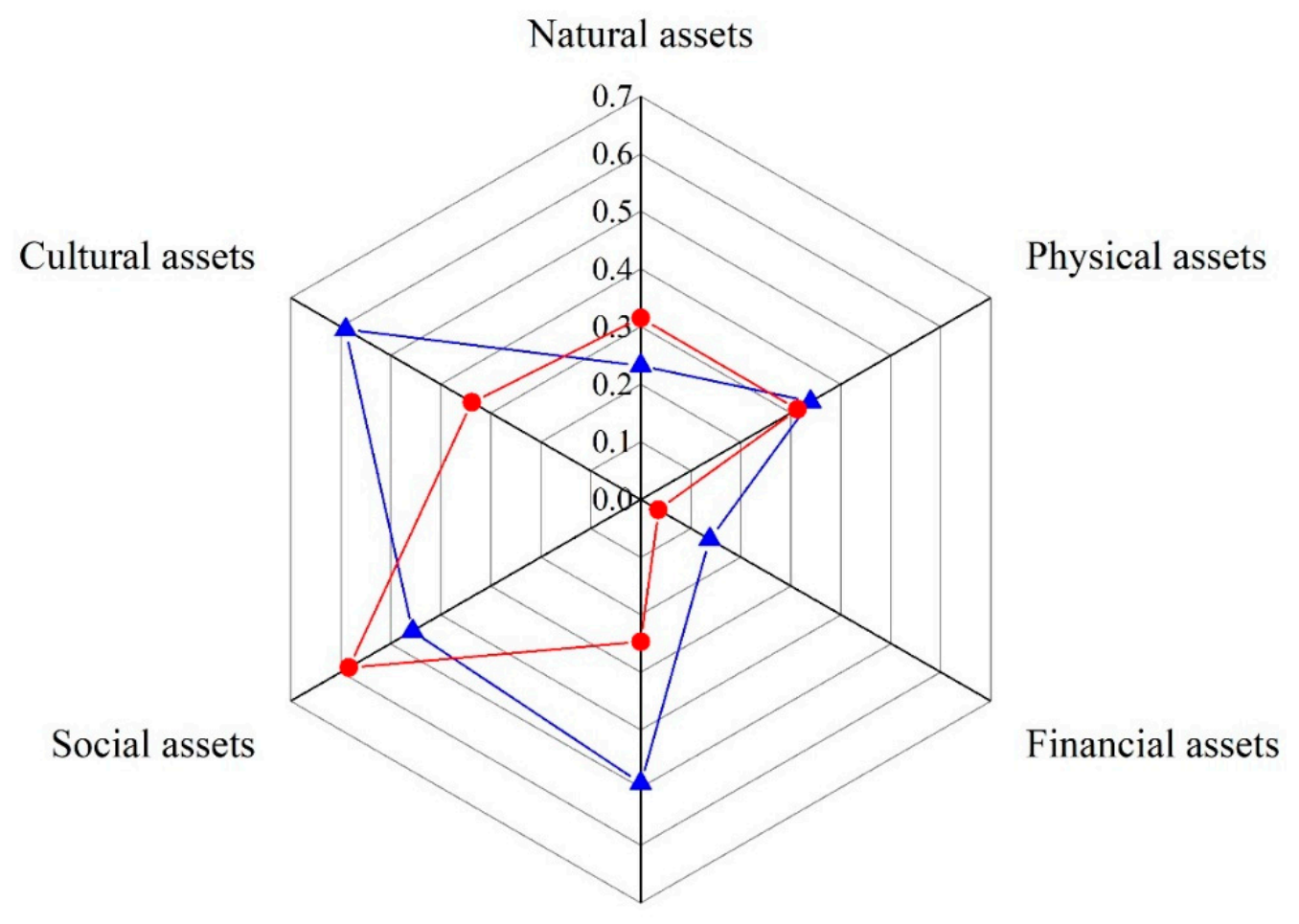

Human assets

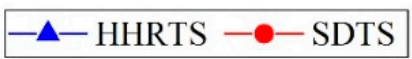

Figure 3. Average livelihood assets of peasant households in HHRTS and SDTS.

Specifically, livelihood assets of households that chose different livelihood strategies are described in the following subsections.

Pure agricultural households (LS1). The livelihood asset value of pure agricultural households in the HHRTS and SDTS is 2.072 and 1.760, respectively. Both values are lower than the average level in the two kinds of terrace systems, which means their livelihood assets are relatively insufficient. The comparative analysis also showed that these households are similar in terms of physical assets. However, HHRTS pure agricultural households have advantages in cultural, human, and financial assets, whereas SDTS pure agricultural households have advantages in natural and social assets (Figure 4). 


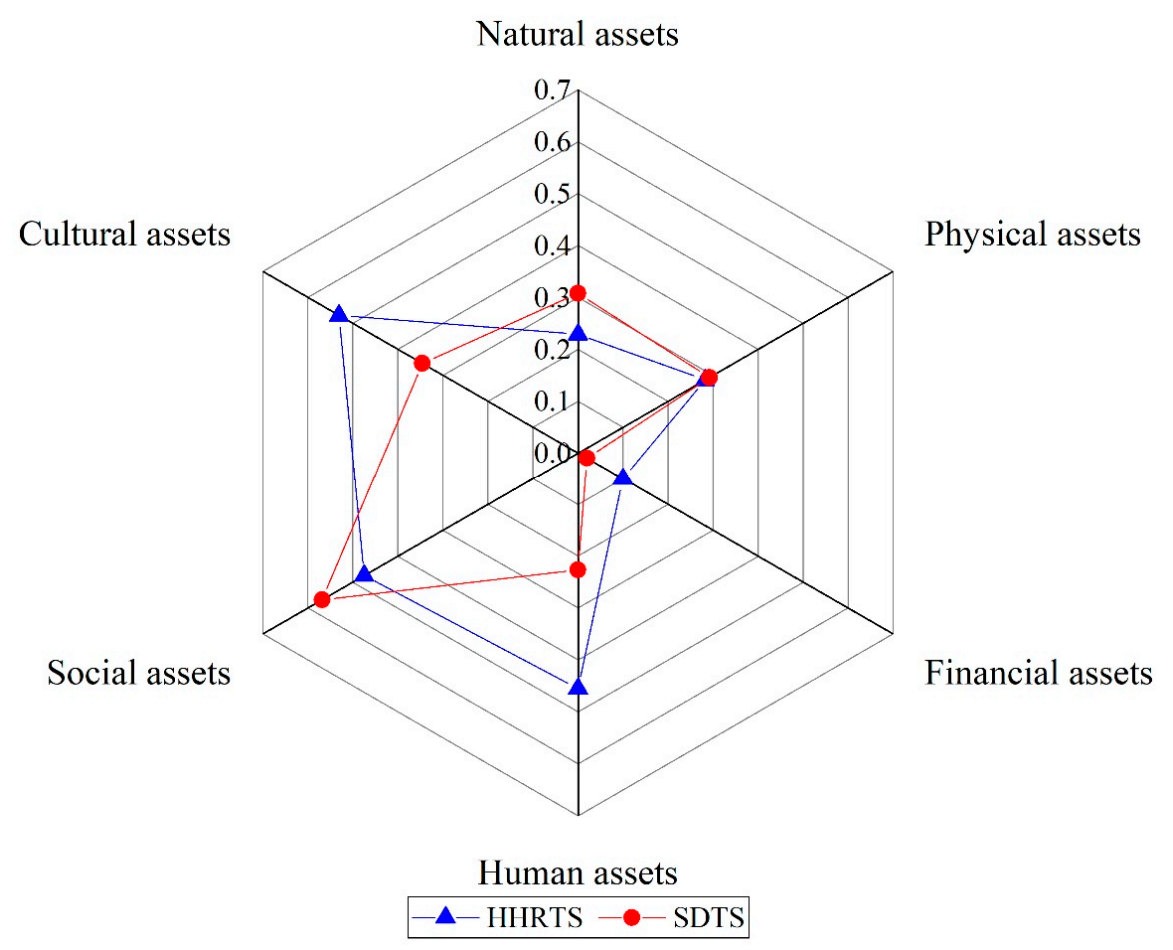

Figure 4. Livelihood assets of pure agricultural households in HHRTS and SDTS.

Nonagricultural households (LS2). The livelihood asset value of nonagricultural households in the HHRTS and SDTS is 2.283 and 1.883, respectively. Both are higher than the average level in the two kinds of terrace systems, which means they have relatively ample livelihood assets. The comparative analysis shows that these households have a similar level of physical assets. HHRTS nonagricultural households have advantages in cultural, human, and financial assets, whereas SDTS nonagricultural households are stronger in terms of natural and social assets (Figure 5).

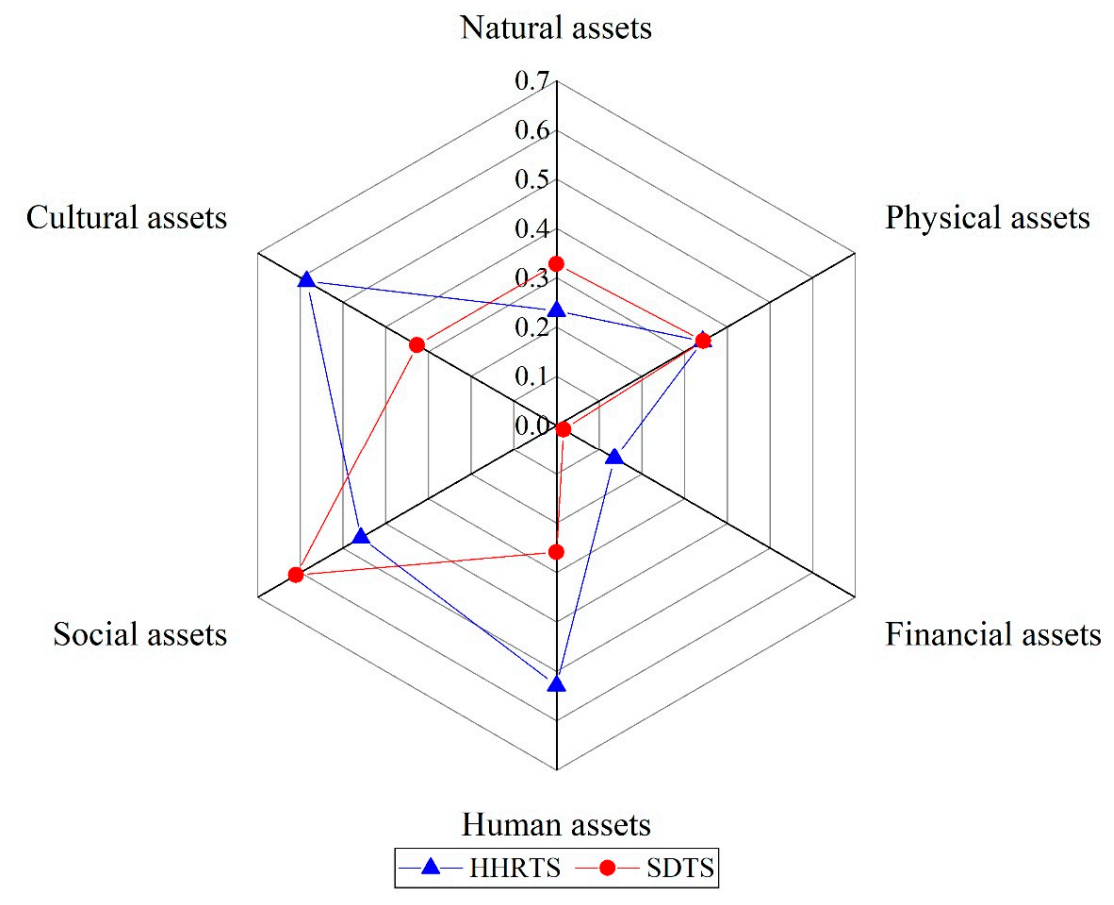

Figure 5. Livelihood assets of nonagricultural households in HHRTS and SDTS. 
Part-time agricultural households (LS3). The livelihood asset value of part-time agricultural households in the HHRTS and SDTS is 2.318 and 1.859, respectively. Both are higher than the average level in the two kinds of terrace systems, which means they have relatively ample livelihood assets. The comparative analysis shows that HHRTS part-time agricultural households have advantages in cultural, human, financial, and physical assets. SDTS part-time agricultural households have advantages in natural and social assets (Figure 6).

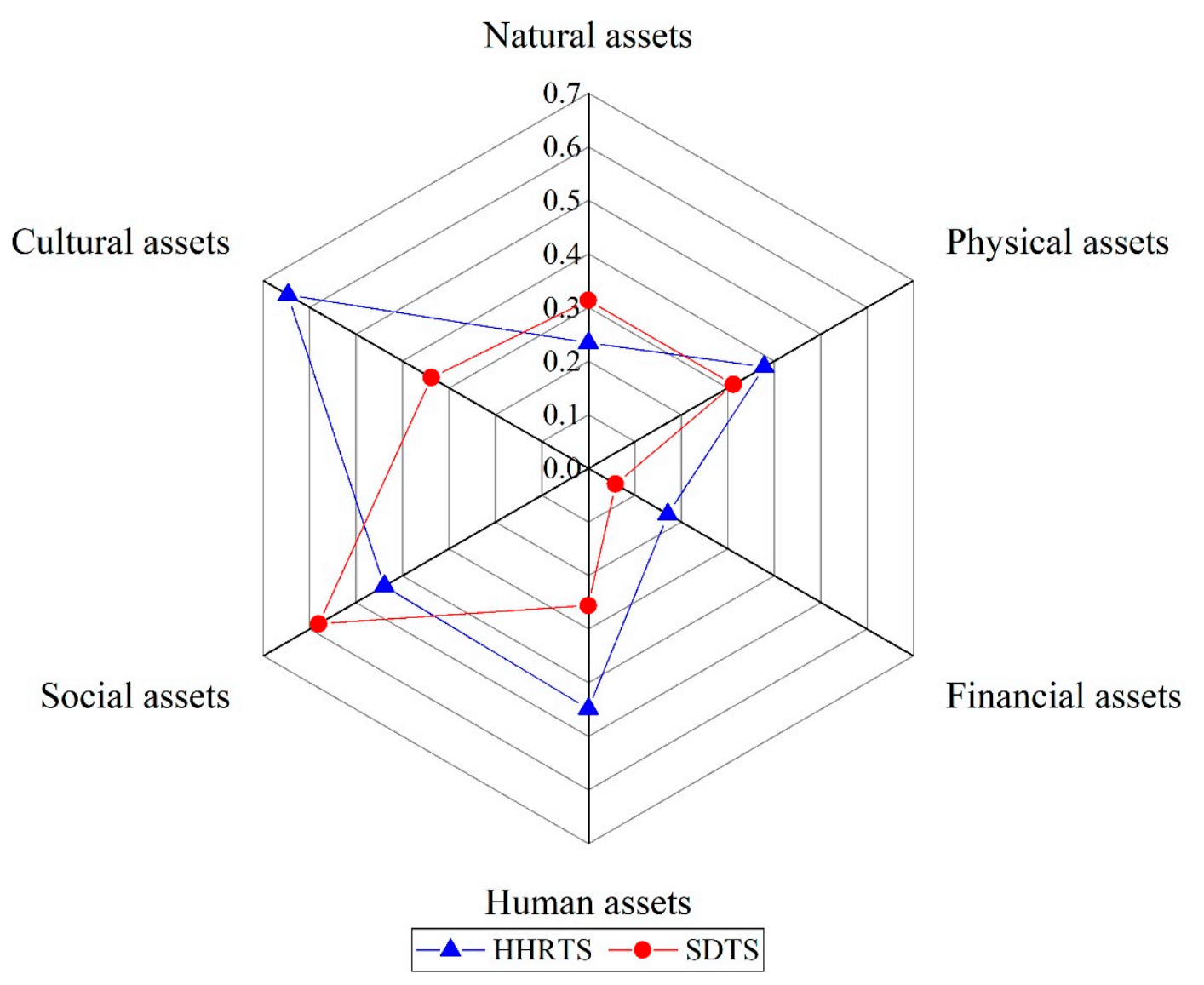

Figure 6. Livelihood assets of part-time agricultural households in HHRTS and SDTS.

\subsection{Effects of Livelihood Assets on Livelihood Strategies}

Both the HHRTS and SDTS are typical terrace systems and representative examples of AHS, where agricultural production is a long-standing livelihood strategy widely used by peasants. Hence, we selected LS1 households as a reference and discuss the livelihood asset indicators that have a significant influence on households when they change from LS1 to LS2 and LS3. The results of the regression analysis are shown in Table 5.

Transformation from LS1 to LS2. HHRTS households receive a significantly positive influence from financial assets and a significantly negative influence from human, cultural, and social assets when they change from LS1 to LS2. Significantly correlated livelihood asset indicators are F1 (+), F2 (+), H3 (-), S2 (-), and C2 (-). In the SDTS, when LS1 households become LS2, they are significantly positively influenced by physical and social assets and significantly negatively influenced by cultural assets. Significantly correlated livelihood assets indicators are P1 (+), S1 (+) and C2 (-). 
Table 5. Results of the multinomial logit model.

\begin{tabular}{|c|c|c|c|c|c|c|c|c|c|}
\hline & & \multicolumn{4}{|c|}{ HHRTS } & \multicolumn{4}{|c|}{ SDTS } \\
\hline & & \multicolumn{2}{|c|}{ LS2 } & \multicolumn{2}{|c|}{ LS3 } & \multicolumn{2}{|c|}{ LS2 } & \multicolumn{2}{|c|}{ LS3 } \\
\hline & & Coefficient & $P>|z|$ & Coefficient & $P>|z|$ & Coefficient & $P>|z|$ & Coefficie & $P>|z|$ \\
\hline \multirow{3}{*}{ Natural assets } & N1 & 1.611 & 0.676 & 0.509 & 0.908 & -0.040 & 0.974 & -0.930 & 0.404 \\
\hline & N2 & -0.428 & 0.643 & 0.347 & 0.743 & 0.374 & 0.550 & $0.513^{* *}$ & 0.035 \\
\hline & N3 & 0.302 & 0.724 & 0.013 & 0.989 & 0.522 & 0.502 & 0.002 & 0.998 \\
\hline \multirow{3}{*}{ Physical assets } & P1 & -2.218 & 0.575 & -0.902 & 0.839 & $1.086^{* *}$ & 0.022 & 0.654 & 0.395 \\
\hline & P2 & -0.943 & 0.510 & 0.488 & 0.783 & 1.034 & 0.338 & 0.629 & 0.515 \\
\hline & P3 & 4.839 & 0.335 & 3.992 & 0.461 & 0.679 & 0.568 & -0.320 & 0.771 \\
\hline \multirow{3}{*}{ Financial assets } & F1 & $67.371 * * *$ & 0.000 & $59.486^{* * *}$ & 0.000 & -0.431 & 0.846 & 1.410 & 0.404 \\
\hline & $\mathrm{F} 2$ & $19.186^{* *}$ & 0.012 & $20.184^{* * *}$ & 0.009 & 2.737 & 0.898 & 14.338 & 0.408 \\
\hline & F3 & -0.332 & 0.642 & -0.096 & 0.896 & -0.828 & 0.737 & $3.381 * *$ & 0.031 \\
\hline \multirow{3}{*}{ Human assets } & $\mathrm{H} 1$ & 0.684 & 0.579 & -0.378 & 0.786 & -0.148 & 0.932 & 0.740 & 0.602 \\
\hline & $\mathrm{H} 2$ & 0.345 & 0.425 & 0.252 & 0.603 & 0.592 & 0.463 & 0.325 & 0.643 \\
\hline & $\mathrm{H} 3$ & $-1.024^{* *}$ & 0.013 & $-0.888^{* *}$ & 0.025 & 0.597 & 0.763 & 1.320 & 0.447 \\
\hline \multirow{3}{*}{ Social assets } & S1 & 0.367 & 0.533 & -0.275 & 0.667 & $0.825^{* *}$ & 0.026 & $0.726^{* *}$ & 0.025 \\
\hline & $\mathrm{S} 2$ & $-1.198^{* *}$ & 0.015 & -0.916 & 0.330 & 0.708 & 0.478 & -0.553 & 0.529 \\
\hline & S3 & 0.158 & 0.764 & 0.138 & 0.817 & 0.353 & 0.645 & 0.162 & 0.806 \\
\hline \multirow{3}{*}{ Cultural assets } & $\mathrm{C} 1$ & 0.429 & 0.694 & 1.394 & 0.282 & 0.697 & 0.516 & $1.986^{* *}$ & 0.042 \\
\hline & $\mathrm{C} 2$ & $-1.004^{* *}$ & 0.028 & $-1.438^{* *}$ & 0.017 & $-1.401 *$ & 0.056 & -0.554 & 0.384 \\
\hline & $\mathrm{C} 3$ & 0.705 & 0.326 & $1.610 *$ & 0.054 & 0.585 & 0.633 & 0.365 & 0.747 \\
\hline Constant & & $1.027^{*}$ & 0.090 & 0.064 & 0.926 & -0.584 & 0.320 & 0.358 & 0.468 \\
\hline
\end{tabular}

In summary, in these two terrace systems, pure agricultural households are significantly influenced by social and cultural assets when they choose to become nonagricultural households. The influence of cultural assets is all positive, whereas the influence of social assets is negative in the HHRTS but positive in the SDTS.

Transformation from LS1 to LS3. HHRTS households receive a significant influence from cultural assets, a significantly positive influence from financial assets, and a significantly negative influence from human assets when transforming from LS1 to LS3. Significantly correlated livelihood asset indicators are F1 (+), F2 (+), H3 (-), C2 (-), and C3 (+). Among SDTS households, natural, financial, social, and cultural assets have a significantly positive influence on households that change from LS1 to LS3. Significantly correlated livelihood asset indicators are N2 (+), F3 (+), S1 (+), and C1 (+).

In summary, in these terrace systems, when a pure agricultural household shifts to a part-time agricultural household, it is significantly influenced by cultural assets. However, the influences of cultural assets on pure agricultural households in the HHRTS are different, as demonstrated by the indicators, and the negative influences have a higher level of significance. They have a positive influence on pure agricultural households in the SDTS.

\section{Discussion}

Terraces are montanic agricultural production systems that are centered on the production and life of households. Both the HHRTS and SDTS still play an important role in production functions. They are typical eco-agricultural models and outstanding ecological and cultural landscapes and, more importantly, they are precious AHS. However, if households that maintain the vitality of agricultural production are lost, all value of the terrace systems will no longer exist [9]. Therefore, to realize sustainable development of AHS, encouraging more households to maintain the livelihood strategy centering on agricultural production is key.

By filtering livelihood asset indicators that influence households in choosing their livelihood strategies acquired from the analysis above, in terrace systems, a household's understanding of traditional agricultural knowledge is the most important indicator in the process of pure agricultural households changing to nonagricultural or part-time agricultural households. Therefore, it is necessary 
to establish a policy intervention mechanism focusing on the conservation of traditional agricultural knowledge (TAK) to realize the dynamic conservation of AHS.

However, it is unfair to impose the pressure of conserving AHS shared by all humankind on households that are made up of vulnerable members of society [3]. Therefore, it is suggested to use a multistakeholder process [70] as a more effective policy intervention mechanism. The stakeholders are identified as local government, rural community, and peasant households (Figure 7).

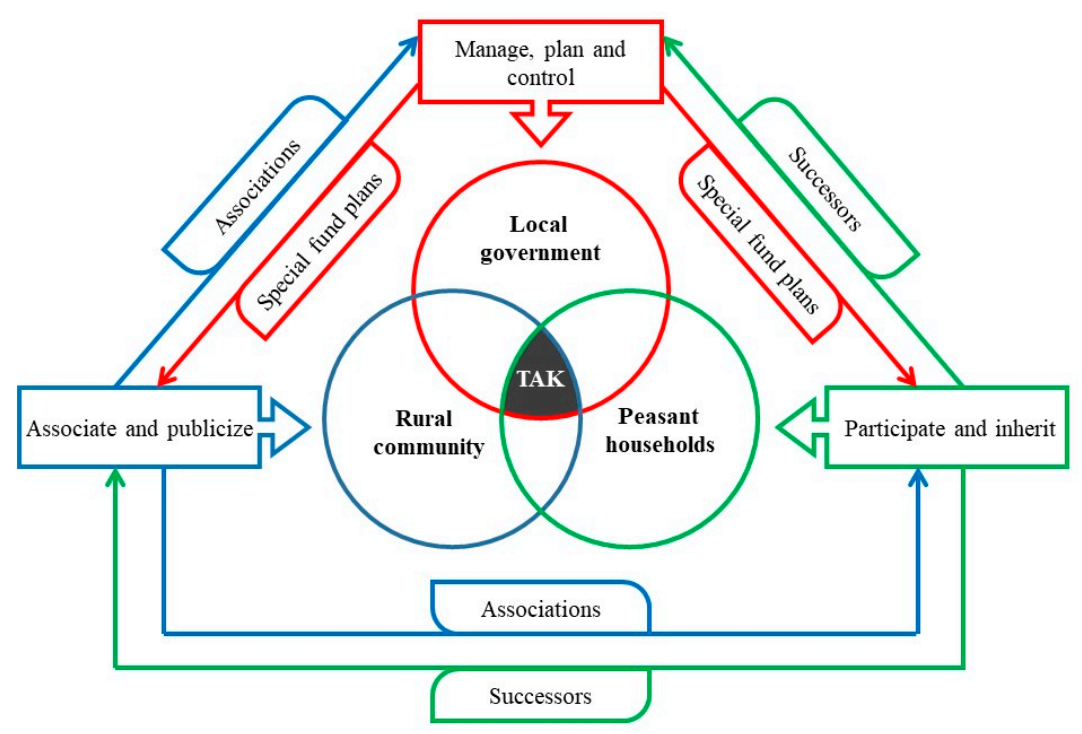

Figure 7. Policy intervention mechanism for conservation and management of traditional agricultural knowledge (TAK).

Local government. As the stakeholder of policy formulation, its main task is to manage, plan, and control the conservation of TAK, by first appointing a foundation committee and establishing special fund plans of TAK conservation; second, formulating programs for the conservation of TAK and organizing their implementation, supervision, and administration; third, incorporating the conservation of TAK into monitoring and evaluation indicator systems of GIAHS. For every GIAHS site, regular monitoring and evaluation are important components of a dynamic conservation plan submitted to the FAO.

Rural community. As the stakeholder of policy implementation, its main task is to promote and popularize TAK among the public with the support of special funds for TAK conservation, and to establish associations and publicize TAK on a regular basis within the community. Meanwhile, it should select, train, and motivate related successors to inherit endangered TAK.

Peasant households. As the stakeholders of policy participation, their main task is to participate in and achieve conservation of TAK under the guidance of the local government and rural community, especially for related successors of TAK. In addition, every household should establish the consciousness of conservation of TAK, and seniors within a household should volunteer to impart agricultural knowledge and techniques to the next generation and enhance young people's understanding of traditional agricultural knowledge.

\section{Conclusions}

On the basis of first-hand data collected via household-level investigations, we compared and analyzed two typical terrace systems, the HHRTS and the SDTS. Livelihood assets of households and types of livelihood strategies were analyzed through a combination of mathematical statistics and quantitative analysis to determine the factors that influence the choice of households' livelihood strategies. The results of the analysis support the following conclusions: 
(1) According to source and structure of income, households in terrace systems can be divided into pure agricultural households, nonagricultural households, and part-time agricultural households. The HHRTS features nonagricultural households and a higher level of nonagriculturalization in household livelihood strategies, whereas the SDTS features part-time agricultural households and a higher level of diversification in agricultural livelihood strategies.

(2) The average livelihood asset value of households in the HHRTS and SDTS is 2.249 and 1.832, respectively. In these two terrace systems, households have similar levels of physical assets, but HHRTS households have advantages in cultural, human, and financial assets. However, SDTS households have advantages in natural and social assets.

(3) In these two terrace systems, compared with average livelihood asset values, livelihood assets of pure agricultural households are lower than the average level, whereas livelihood assets of nonagricultural and part-time agricultural households are higher than average. Furthermore, in the HHRTS, part-time agricultural households have the highest value for livelihood assets, whereas in the SDTS, nonagricultural households have the highest.

(4) In these two terrace systems, pure agricultural households are significantly influenced by social and cultural assets when choosing to become nonagricultural households, and they are significantly influenced by cultural assets when choosing to become part-time agricultural households. Overall, among cultural assets, a household's understanding of traditional agricultural knowledge is an important factor that restrains pure agricultural households from becoming nonagricultural or part-time agricultural households. Therefore, to ensure the dynamic conservation of terrace systems, it is advisable to effectively improve cultural assets among households, especially their understanding of traditional agricultural knowledge. In addition, a livelihood strategy should be promoted that centers on maintaining agricultural production among households in order to ultimately realize the sustainable development of terrace systems.

Due to the complexity of the issue and availability of data, this paper has several deficiencies that can be subjects of further study. First, this paper tentatively introduces the concept of cultural assets and includes it in the agricultural livelihood strategy assessment framework to highlight the important role played by traditional culture and information technology in livelihood activities in AHS. The design of indicators focuses on subjective evaluative indicators for households and lacks an objective descriptive indicator, because there is a lack of systematic studies of cultural assets in academia. Second, the analysis of the influence of household livelihood assets on the selection of livelihood strategy only uses cross-sectional data for a single year, and a long time span was not included. On the basis of these limitations, we aim to expand the collection of sample data and conduct a regular and long-term study in the study area.

Author Contributions: L.Y. and Q.M. conceived and designed the research; L.Y., F.L., and C.Z. collected and analyzed the data of HHRTS; L.Y., F.L., and H.L. collected and analyzed the data of SDTS; L.Y. and M.L. developed the model, conducted the analysis, and wrote the paper together.

Funding: This work was supported by the National Key R\&D Program of China (No. 2017YFC0506402) and the National Social Science Fund of China (No. 17CSH012).

Conflicts of Interest: The authors declare no conflict of interest.

\section{References}

1. What Are GIAHS? Available online: http:/ /www.fao.org/giahs/giahs/en/ (accessed on 24 August 2013).

2. Yang, L.; Liu, M.C.; Lun, F.; Yuan, Z.; Zhang, Y.X.; Min, Q.W. An analysis on crops choice and its driving factors in agricultural heritage systems-A case of Honghe Hani Rice Terraces System. Sustainability 2017, 9, 1162. [CrossRef]

3. Min, Q.W.; Zhang, Y.X.; Jiao, W.J.; Sun, X.P. Responding to common questions on the conservation of agricultural heritage systems in China. J. Geogr. Sci. 2016, 26, 969-982. [CrossRef]

4. GIAHS around the World. Available online: http://www.fao.org/giahs/giahsaroundtheworld/en/ (accessed on 26 June 2018). 
5. China-NIAHS around the China. Available online: http://www.moa.gov.cn/ztzl/zywhycsl/ (accessed on 26 June 2018).

6. Fukamachi, K. Sustainability of terraced paddy fields in traditional satoyama landscapes of Japan. J. Environ. Manag. 2016, 202 Pt 3, 543-549. [CrossRef] [PubMed]

7. Krahtopoulou, A.; Frederick, C. The stratigraphic implications of long term terrace agriculture in dynamic landscapes: Polycyclic terracing from Kythera Island, Greece. Geoarchaeology 2008, 23, 550-585. [CrossRef]

8. Tarolli, P.; Preti, F.; Romano, N. Terraced landscapes: From an old best practice to a potential hazard for soil degradation due to land abandonment. Anthropocene 2014, 6, 10-25. [CrossRef]

9. Wei, W.; Chen, D.; Wang, L.X.; Daryanto, S.; Chen, L.D.; Yu, Y.; Lu, Y.L.; Sun, G.; Feng, T.J. Global synthesis of the classifications, distributions, benefits and issues of terracing. Earth-Sci. Rev. 2016, 159, 388-403. [CrossRef]

10. Kosmowski, F. Soil water management practices (terraces) helped to mitigate the 2015 drought in Ethiopia. Agric. Water Manag. 2018, 204, 11-16. [CrossRef] [PubMed]

11. Pietsch, D.; Mabit, L. Terrace soils in the Yemen Highlands: Using physical, chemical and radiometric data to assess their suitability for agriculture and their vulnerability to degradation. Geoderma 2012, 185, 48-60. [CrossRef]

12. Calderon, M.M.; Bantayan, N.C.; Dizon, J.T.; Sajise, A.J.U.; Codilan, A.L.; Canceran, M.S. Community-Based Resource Assessment and Management Planning for the Rice Terraces of Hungduan, Ifugao, Philippines. J. Environ. Sci. Manag. 2015, 18, 47-53.

13. Zhang, Y.X.; Min, Q.W. A review of conservation of rice terraces as agricultural heritage systems. Chin. J. Eco-Agric. 2016, 24, 460-469. (In Chinese with English Abstract) [CrossRef]

14. Zhang, Y.X.; Min, Q.W.; Zhang, C.Q.; He, L.L.; Zhang, S.; Yang, L.; Tian, M.; Xiong, Y. Traditional culture as an important power for maintaining agricultural landscapes in cultural heritage sites: A case study of the Hani terraces. J. Cult. Heritage 2017, 25, 170-179. [CrossRef]

15. Chen, D.; Wei, W.; Chen, L. Effects of terracing practices on water erosion control in China: A meta-analysis. Earth-Sci. Rev. 2017, 173, 109-121. [CrossRef]

16. Li, J.; Min, Q.W.; Li, W.H.; Bai, Y.Y.; Yang, L.; Bijaya, G.C.D. Evaluation of water resources conserved by forests in the Hani rice terraces system of Honghe County, Yunnan, China: An application of the fuzzy comprehensive evaluation model. J. Mt. Sci. 2016, 13, 744-753. [CrossRef]

17. Hani Rice Terraces. Available online: http://www.fao.org/giahs/giahsaroundtheworld/designated-sites/ asia-and-the-pacific/hani-rice-terraces/en/ (accessed on 26 June 2018).

18. Cultural Landscape of Honghe Hani Rice Terraces. Available online: http://whc.unesco.org/en/list/1111/ (accessed on 26 June 2018).

19. He, X.L. The Origins, Classifications and Features of Dry Land Terrace Farming System of Shexian County, Hebei Province. China Agric. Univ. J. Soc. Sci. Ed. 2017, 34, 84-94. (In Chinese with English Abstract) [CrossRef]

20. Zhang, F.F.; Zhao, X.Y. A review of ecological effect of peasant's livelihood transformation in China. Acta Ecol. Sin. 2015, 35, 3157-3164. (In Chinese with English Abstract) [CrossRef]

21. Mubaya, C.P.; Mafongoya, P. Local-level climate change adaptation decision-making and livelihoods in semi-arid areas in Zimbabwe. Environ. Dev. Sustain. 2017, 19, 2377-2403. [CrossRef]

22. Musinguzi, L.; Efitre, J.; Odongkara, K.; Ogutu-Ohwayo, R.; Muyodi, F.; Natugonza, V.; Olohotum, M.; Namboowa, S.; Naigaga, S. Fishers' perceptions of climate change, impacts on their livelihoods and adaptation strategies in environmental change hotspots: A case of Lake Wamala, Uganda. Environ. Dev. Sustain. 2016, 18, 1255-1273. [CrossRef]

23. Taboada, C.; Garcia, M.; Gilles, J.; Pozo, O.; Yucra, E.; Rojas, K. Can warmer be better? Changing production systems in three Andean ecosystems in the face of environmental change. J. Arid Environ. 2017. [CrossRef]

24. Liu, M.C.; Xiong, Y.; Yuan, Z.; Min, Q.W.; Sun, Y.H.; Fuller, A.M. Standards of ecological compensation for traditional eco-agriculture: Taking rice-fish system in Hani terrace as an Example. J. Mt. Sci. 2014, 11, 1049-1059. [CrossRef]

25. Bai, Y.; Min, Q.W.; Liu, M.C.; Yuan, Z.; Xu, Y.; Cao, Z.; Li, J. Resilience of the Hani Rice Terraces System to extreme drought. J. Food Agric. Environ. 2013, 11, 2376-2382. 
26. Liu, S.L.; Dong, Y.H.; Li, D.; Liu, Q.; Wang, J.; Zhang, X.L. Effects of different terrace protection measures in a sloping land consolidation project targeting soil erosion at the slope scale. Ecol. Eng. 2013, 53, 46-53. [CrossRef]

27. Tian, M.; Min, Q.W.; Jiao, W.J.; Yuan, Z.; Fuller, A.M.; Yang, L.; Zhang, Y.X.; Zhou, J.; Cheng, B. Agricultural Heritage Systems Tourism: Definition, characteristics and development framework. J. Mt. Sci. 2016, 13, 440-454. [CrossRef]

28. Xu, Y.Q.; Li, K.Q. Protection and development of Hani terraced agricultural cultural heritage in Honghe County. Agric. Archaeol. 2013, 1, 279-281. (In Chinese with English Abstract)

29. Liu, M.C.; Min, Q.W.; Yang, L. Rice Pricing during Organic Conversion of the Honghe Hani Rice Terrace System in China. Sustainability 2018, 10, 183. [CrossRef]

30. Wang, L.; Wang, L.; Yang, B.H.; Li, J. Preliminary study on Hani terraced-field water culture and its protection. China Rural Water Hydropower 2007, 8, 42-44. (In Chinese with English Abstract)

31. Hu, W.Y.; Jiao, Y.M.; Fan, T. Research on Information Tupu of Land Use Spatial Pattern and Its Change in Hani Terraced Fields. Sci. Geogr. Sin. 2008, 28, 419-424. (In Chinese with English Abstract)

32. Menconi, M.E.; Grohmann, D.; Mancinelli, C. European farmers and participatory rural appraisal: A systematic literature review on experiences to optimize rural development. Land Use Policy 2017, 60, 1-11. [CrossRef]

33. Department for International Development (DFID). Better Livelihoods for Poor People: The Role of Agriculture; Department for International Development: London, UK, 2002.

34. Department for International Development (DFID). Sustainable Livelihoods Guidance Sheets; Department for International Development: London, UK, 1999.

35. Carter, M.R.; Little, P.D.; Mogues, T.; Negatu, W. Poverty traps and natural disasters in Ethiopia and Honduras. World Dev. 2007, 35, 835-856. [CrossRef]

36. Perge, E.; Mckay, A. Forest clearing, livelihood strategies and welfare: Evidence from the Tsimane' in Bolivia. Ecol. Econ. 2016, 126, 112-124. [CrossRef]

37. Lax, J.; Köthke, M. Livelihood strategies and forest product utilisation of rural households in Nepal. Small-Scale For. 2017, 16, 505-520. [CrossRef]

38. Tang, Q.; Xu, Y.; Li, Y. Assessment of farmers' sustainable livelihoods and future strategies on the Loess Plateau: Based on a survey of 1076 farmers in Yan'an City in Shaanxi Province and Guyuan City in Ningxia Hui Autonomous Region. Prog. Geogr. 2013, 32, 161-169. (In Chinese with English Abstract)

39. Wu, Y.T.Y.; Yang, J. Evolution path of household's livelihood strategies and its impact on agricultural land use patterns: Based on the investigation of 291 farmer households in Hunan. J. Hunan Agric. Univ. (Soc. Sci.) 2017, 18, 65-69. (In Chinese with English Abstract)

40. Wan, W.Y.; Zhao, X.Y.; Wang, W.J.; Xue, B. Farmers' livelihood risk in Ecologically Vulnerable Alpine Region: A case of Gannan Plateau. Econ. Geogr. 2017, 37, 149-157. (In Chinese with English Abstract)

41. Van den Berg, M. Household income strategies and natural disasters: Dynamic livelihoods in rural Nicaragua. Ecol. Econ. 2010, 69, 592-602. [CrossRef]

42. Fang, S.U.; Saikia, U.; Hay, I. Relationships between Livelihood Risks and Livelihood Capitals: A Case Study in Shiyang River Basin, China. Sustainability 2018, 10, 509. [CrossRef]

43. Liu, Z.F.; Chen, Q.R.; Xie, H.L. Influence of the Farmer's Livelihood Assets on Livelihood Strategies in the Western Mountainous Area, China. Sustainability 2018, 10, 875. [CrossRef]

44. Gautam, Y.; Andersen, P. Rural livelihood diversification and household well-being: Insights from Humla, Nepal. J. Rural Stud. 2016, 44, 239-249. [CrossRef]

45. Hua, X.B. The Coupling between Livelihood of Farmers and Herders and Land Use-Case Studies of Three Agro-Ecological Zones in Tibetan Plateau; Southwest University: Chongqing, China, 2014. (In Chinese with English Abstract)

46. Zhang, C.Q.; Min, Q.W.; Zhang, H.Z.; Zhang, Y.X.; Tian, M.; Xiong, Y. Analysis on the rural households livelihoods aiming at the conservation of agricultural heritage systems. China Popul. Resour. Environ. 2017, 27, 169-176. (In Chinese with English Abstract) [CrossRef]

47. Koczberski, G.; Curry, G.N. Making a living: Land pressures and changing livelihood strategies among oil palm settlers in Papua New Guinea. Agric. Syst. 2005, 85, 324-339. [CrossRef] 
48. Chen, H.; Zhu, T.; Krott, M.; Calvo, J.F.; Ganesh, S.P.; Makoto, I. Measurement and evaluation of livelihood assets in sustainable forest commons governance. Land Use Policy 2013, 30, 908-914. [CrossRef]

49. Khatiwada, S.P.; Deng, W.; Paudel, B.; Khatiwada, J.R.; Zhang, J.F.; Su, Y. Household livelihood strategies and implication for poverty reduction in rural areas of central Nepal. Sustainability 2017, 9, 612. [CrossRef]

50. Hua, X.; Yan, J.; Zhang, Y.L. Evaluating the role of livelihood assets in suitable livelihood strategies: Protocol for anti-poverty policy in the Eastern Tibetan Plateau, China. Ecol. Indic. 2017, 78, 62-74. [CrossRef]

51. Scoones, I. Sustainable Rural Livelihoods: A Framework for Analysis. Available online: $\quad$ https: / / www.google.com/url?sa=t\&rct=j\&q=\&esrc=s\&source=web\&cd=1\&ved= OahUKEwidpemb9ancAhXJMt4KHUx1CrkQFggsMAA\&url=https\%3A\%2F\%2Fwww.researchgate.net \% 2Fprofile\%2FIan_Scoones\%2Fpublication\%2F251873585_Sustainable_Rural_Livelihoods_A_Framework_ for_Analysis\%2Flinks\%2F5561c41808ae6f4dcc94f72b\%2FSustainable-Rural-Livelihoods-A-Frameworkfor-Analysis.pdf\&usg=AOvVaw3myi2deL-ZCpgUfNg1h35K (accessed on 17 July 2018).

52. Li, Z.; Yan, J.; Hua, X.; Xin, L.; Li, X. Factors influencing the cultivated land abandonment of households of different types: A case study of 12 typical villages in Chongqing Municipality. Geogr. Res. 2014, 33, 721-734.

53. Gu, H.Y.; Jiao, Y.M.; Liang, L.H. Strengthening the socio-ecological resilience of forest-dependent communities: The case of the Hani Rice Terraces in Yunnan, China. For. Policy Econ. 2012, 22, 53-59. [CrossRef]

54. Li, H.Y. Farming and Living: The Donkey Culture of the Dryland Terrace Agriculture System. China Agric. Univ. J. Soc. Sci. Ed. 2017, 34, 103-110. (In Chinese with English Abstract)

55. StataCorp LP. Stata Statistical Software: Release 14; StataCorp LP: College Station, TX, USA, 2015.

56. Guo, X.L.; Zhou, L.H.; Chen, Y.; Yang, G.J.; Zhao, M.M.; Wang, R. Impact of Farmers' Livelihood Capital on Livelihood Strategy in a Typical Desertification Area in the Inner Mongolia Autonomous Region. Acta Ecol. Sin. 2017, 37, 6963-6972. (In Chinese with English Abstract)

57. Zhao, X.Y. The impact of livelihood capital on the life satisfaction of peasants and herdsmen: A case of Gannan Plateau. Geogr. Res. 2011, 30, 687-698. [CrossRef]

58. Wei, G.W. Maximizing deviation method for multiple attribute decision making in intuitionistic fuzzy setting. Knowl.-Based Syst. 2008, 21, 833-836. [CrossRef]

59. Wang, Z.; Liu, Z. Take Measures: Knowledge Poverty Alleviation for Contiguous Poor Areas-A Case Study of the Wuling Mountain Area. Stud. Sociol. Sci. 2014, 5, 20-27. [CrossRef]

60. Hempelmann, C.F.; Sakoglu, U.; Gurupur, V.P.; Jampana, S. An entropy-based evaluation method for knowledge bases of medical information systems. Expert Syst. Appl. 2016, 46, 262-273. [CrossRef]

61. Bryceson, D.F. Deagrarianization and rural employment in sub-Saharan Africa: A sectoral perspective. World Dev. 1996, 24, 97-111. [CrossRef]

62. Soini, E. Land use change patterns and livelihood dynamics on the slopes of Mt. Kilimanjaro, Tanzania. Agric. Syst. 2005, 85, 306-323. [CrossRef]

63. Naidu, S.C. Legal exclusions, private wealth and livelihoods: An analysis of work time allocation in protected areas. Ecol. Econ. 2013, 89, 82-91. [CrossRef]

64. Diniz, F.H.; Hoogstra-Klein, M.A.; Kok, K.; Arts, B. Livelihood strategies in settlement projects in the Brazilian Amazon: Determining drivers and factors within the Agrarian Reform Program. J. Rural Stud. 2013, 32, 196-207. [CrossRef]

65. Davis, J.; Lopezcarr, D. Migration, remittances and smallholder decision-making: Implications for land use and livelihood change in Central America. Land Use Policy 2014, 36, 319-329. [CrossRef] [PubMed]

66. Yan, J.; Wu, Y.; Zhang, Y.; Zhou, S. Livelihood diversification of farmers and nomads of eastern transect in Tibetan Plateau. J. Geogr. Sci. 2010, 20, 757-770. [CrossRef]

67. Bhandari, P.B. Rural livelihood change? Household capital, community resources and livelihood transition. J. Rural Stud. 2013, 32, 126-136. [CrossRef] [PubMed]

68. Reenberg, A.; Maman, I.; Oksen, P. Twenty years of land use and livelihood changes in SE-Niger: Obsolete and short-sighted adaptation to climatic and demographic pressures? J. Arid Environ. 2013, 94, 47-58. [CrossRef] 
69. Brus, D.J.; Slim, P.A.; Gort, G.; Heidema, A.H.; Dobben, H. Monitoring habitat types by the mixed multinomial logit model using panel data. Ecol. Indic. 2016, 67, 108-116. [CrossRef]

70. Denny, J.M.; Case, P.M.; Metzger, A.; Ivanova, M.; Asfaw, A. Power in participatory processes: Reflections from multi-stakeholder workshops in the Horn of Africa. Sustain. Sci. 2018, 13, 879-893. [CrossRef]

(C) 2018 by the authors. Licensee MDPI, Basel, Switzerland. This article is an open access article distributed under the terms and conditions of the Creative Commons Attribution (CC BY) license (http:/ / creativecommons.org/licenses/by/4.0/). 